\title{
Correction to: What composes desirable formal at-home elder care? An analysis for multiple service combinations
}

\author{
Shinya Sugawara ${ }^{1}[$
}

Published online: 15 December 2020

() Japanese Economic Association 2020

\section{Correction to: The Japanese Economic Review https://doi.org/10.1007/s42973-019-00031-w}

The article "What composes desirable formal at-home elder care? An analysis for multiple service combinations", written by Shinya Sugawara, was originally published electronically on the publisher's internet portal on 21 January 2020 without open access. With the author' decision to opt for Open Choice the copyright of the article changed on 6 November 2020 to $\odot$ Author(s) 2020 and the article is forthwith distributed under a Creative Commons Attribution 4.0 International License, which permits use, sharing, adaptation, distribution and reproduction in any medium or format, as long as you give appropriate credit to the original author(s) and the source, provide a link to the Creative Commons licence, and indicate if changes were made. The images or other third party material in this article are included in the article's Creative Commons licence, unless indicated otherwise in a credit line to the material. If material is not included in the article's Creative Commons licence and your intended use is not permitted by statutory regulation or exceeds the permitted use, you will need to obtain permission directly from the copyright holder. To view a copy of this licence, visit http://creativecommons.org/licenses/by/4.0.

The original article has been corrected.

The original article can be found online at https://doi.org/10.1007/s42973-019-00031-w.

Shinya Sugawara

shinya_sugawara@rs.tus.ac.jp

1 Tokyo University of Science, 1-11-2 Fujimi, Chiyoda, Tokyo 102-0071, Japan 